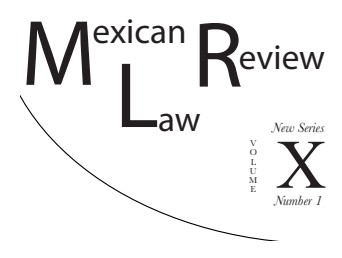

\title{
MINORITY RIGHTS FOR IMMIGRANTS: FROM MULTICULTURALISM TO GIVIG PARTICIPATION
}

\author{
Elisa Ortega VeláZQuez*
}

\begin{abstract}
This article asserts that according to international lawe, immigrants do have rights as a minority, and in abiding by their international obligations, States are obligated to implement policies that safeguard these rights and, in this way, facilitate the integration of immigrants into the host society. However, there are a number of elements that make the practical enforcement of these rights and the implementation of such policies rather complex. Thus, a series of international law provisions are first reviewed so as to be able to establish the foundations of our viewes. Secondly, we summarize and analyze the main trends of integration policies in three of the main Western immigration countries: Canada, the United States and the Netherlands, in order to broadly present the actions and results. Lastly, we conclude that immigrant integration projects fail to respect immigrants' rights as a minority and that more effort should be made to comply with the international obligations States have assumed
\end{abstract}

Key Words: Immigrants, multiculturalism, civic participation, human rights, minorities.

RESUMEN: Este artículo sostiene que, de acuerdo con el derecho internacional, los inmigrantes tienen derechos como minoría, y que los Estados, de conformidad con sus obligaciones internacionales, están obligados a implementar políticas que aseguren estos derechos y, en este sentido, faciliten su integración en las sociedades de acogida. Sin embargo, hay un número de elementos que hacen que el cumplimiento práctico de estos derechos y la aplicación de dichas políticas sea compleja. Entonces, primero, se revisa una serie de disposiciones de derecho internacional con el fin de establecer las bases para apoyar nuestras posturas. Segundo, resumimos y analizamos las principales tendencias en las políticas de integración de tres de los países occidentales más importantes de inmigración: Canadá, Estados Unidos y Países Bajos, con el fin de presentar grosso modo

* Full time researcher in the field of International Law at the Instituto de Investigaciones Jurídicas, UNAM. Doctor of Law and Master in Public Law, Universidad Carlos III de Madrid. Bachelor of Laws, Instituto Tecnológico Autónomo de México. Email: elisaov@unam. mx. 
Esta revista forma parte del acervo de la Biblioteca Jurídica Virtual del Instituto de Investigaciones Jurídicas de la UNAM www.juridicas.unam.mx

las acciones y los resultados. Finalmente, concluimos que los proyectos de integración de los inmigrantes fallan en respetar los derechos de los inmigrantes como minoría y que se deben realizar mayores esfuerzos con el fin de cumplir con las obligaciones internacionales que los Estados han adquirido.

Palabras Clave: Inmigrantes, multiculturalismo, participación cívica, derechos humanos, minorías.

TABLE OF CONTENTS:

I. INTRODUCTION.

II. International LaW Standards FOR MinORities

AND THEIR ApPlication to ImMigrants

1. Declaration on the Rights of Persons Belonging to National or Ethnic, Religious and Linguistic Minorities.

2. Other Instruments.

3. Minority Rights for Immigrants.

III. IMmigrants' InTEGRATION MODELS: From Multiculturalism to Givic Participation.

1. Multiculturalism

A. Canadian Multiculturalism.

B. US Multiculturalism.

2. Civic Integration and Citizechip Trajectories......

Dutch Civic Participation Integration Program.

3. Lessons Learned

\section{INTRODUCTION}

A frequent question is whether immigrants have rights as a minority. However, it should be noted that under the provisions of human rights instruments, States have the obligation to protect the rights of all persons subject to or under their jurisdictions. These instruments are drafted in an inclusive language (all, everyone, etc.) and - generally - protect all persons without discrimination, regardless of their citizenship or immigration status. Explicit exceptions to this principle relate, inter alia, to political rights ${ }^{1}$ and freedom of movement, ${ }^{2}$ but not to minority rights. Therefore, regardless of their culture,

1 See International Covenant on Civil and Political Rights Article 25, Dec. 16, 1966, GA Res. 2200A (XXI).

2 Id., Article 12.1. 
religion, national original, race, religion, language, ethnic group, or even immigration status, immigrants are all equally entitled as citizens to - mosthuman rights (with the generally accepted exceptions mentioned above). Thus, in the first section of this article, we will examine certain human rights law provisions regarding minority rights and their application to immigrants.

In the second section, we show that, despite the fact that international law affords minority rights to immigrants, there are a number of elements that make the practical application and enforcement of these rights to immigrants rather complex. For this purpose, we study the experience of three migration receiving countries (Canada, the United States and the Netherlands) and their integration policies. Our aim is to track some of the elements that have influenced and reshaped their immigration integration programs. The cases selected encompass the most representative trends in the world, and the immigration models that several other receiving countries are now trying to implement in an attempt to control, and ultimately establish a selective program so as to attain their objectives of making immigration a cornerstone for population and economic advancement.

\section{INTERNATIONAL LAW StandARDS FOR MiNORITIES AND THEIR Application to ImmigRants}

\section{Declaration on the Rights of Persons Belonging \\ to National or Ethnic, Religious and Linguistic Minorities}

This Declaration ${ }^{3}$ is the main reference document for minority rights. As set out in the resolution and the preamble to the Declaration, its purpose is to promote a more effective implementation of the human rights of persons belonging to minorities. The Declaration is inspired by Article 27 of the International Covenant on Civil and Political Rights, which states that: "In those States in which ethnic, religious or linguistic minorities exist, persons belonging to such minorities shall not be denied the right, in community with the other members of their group, to enjoy their own culture, to profess and practice their own religion, or to use their own language".

This article protects the rights of persons belonging to minorities, their national, ethnic, religious or linguistic identity, or a combination thereof, and to preserve the characteristics they wish to maintain and develop. Although it refers to the rights of minorities in the States in which they exist, its applicability is not subject to a State's official recognition of a minority. States that have ratified the Covenant are obliged to ensure that all individuals under

3 Declaration on the Rights of Persons Belonging to National or Ethnic, Religious and Linguistic Minorities, Dec. 18, 1992, GA Res. 47/135, UN Doc. HR/PUB/10/3, 15. 
their jurisdiction enjoy their rights; this may require specific actions to correct inequalities to which minorities are subjected. ${ }^{4}$

Human Rights Committee General Comment Num. 23 (1994) on the rights of minorities provides an authoritative interpretation of Article 27. The Committee states that "this article establishes and recognizes a right which is conferred on individuals belonging to minority groups and which is distinct from, and additional to, all the other rights which, as individuals in common with everyone else, they are already entitled to enjoy under the Covenant." ${ }^{5}$ The right under Article 27 is an autonomous one within the Covenant. The Human Rights Committee's interpretation of its scope of application has had the effect of ensuring the recognition of the existence of diverse groups within a State and of the fact that decisions on such recognition are not the province of the State alone. Moreover, that positive measures implemented by States may be "necessary to protect the identity of a minority and the rights of its members to enjoy and develop their culture and language and to practice their religion, in community with the other members of the group."

The beneficiaries of the rights under Article 27 of the International Covenant on Civil and Political Rights, which inspired the Declaration, are persons belonging to "ethnic, religious or linguistic minorities." The Declaration reiterates this assertion, but adds the term "national minorities." To this respect, in 2005 the Working Group on Minorities declared that: "there is hardly any national minority [...] that is not also an ethnic or linguistic minority."

The Declaration builds on and adds to the rights contained in the International Bill of Human Rights and other human rights instruments by strengthening and clarifying those rights which make it possible for persons belonging to minorities to preserve and develop their group identity. In particular, the Declaration grants to persons belonging to minorities: State protection of their existence and their national or ethnic, cultural, religious and linguistic identity (Article 1); the right to enjoy their own culture, to profess and practice their own religion, and to use their own language in private and in public (Article 2[1]); the right to participate effectively in cultural, religious, social, economic and public life (Article 2 [2]); the right to participate effectively in decisions which affect them on the national and regional levels (Article 2 [3]); the right to establish and maintain their own associations (Article 2 [4]); the

4 See A. Buchanan \& D. Mathieu, Philosophy and Fustice, in Justice: Views from the Social Sciences (R. L. Cohen ed., 1986); Oddny Mjöll Arnardóttir, Equality and nondiscrimination under the European Convention on Human Rights (Martinus Nijhoff Publishers; Norwell, MA; Kluwer Law International 2003).

5 UN Human Rights Committee, General Comment num. 23: The rights of minorities (Article 27), UN Doc CGPR/C/21/Rev.1/Add. 5, (1994), par. 1.

6 Id., para. 2.

7 UN Commission on Human Rights, Commentary of the Working Group on Minorities to the United Nations Declaration on the rights of persons belonging to national or ethnic, religious and linguistic minorities, UN Doc E/CN.4/Sub.2/AC.5/2005/2, (2005), par. 6. 
right to establish and maintain peaceful contacts with other members of their group and with persons belonging to other minorities, both within their own country and across State borders (Article 2 [5]); and the freedom to exercise their rights, individually as well as in community with other members of their group, without discrimination (Article 3).

States must ensure the protection and promotion of the rights of persons belonging to minorities by taking measures to ensure that they may fully and effectively exercise all their human rights and fundamental freedoms without any discrimination and in full equality before the law (Article 4 [1]); create favorable conditions to enable persons belonging to minorities to express their characteristics and to develop their culture, language, religion, traditions and customs (Article 4 [2]); allow these persons adequate opportunities to learn their mother tongue or to have instruction in their mother tongue (Article 4 [3]); encourage knowledge of the history, traditions, language and culture of minorities existing within their territory and ensure that members of such minorities have adequate opportunities to gain knowledge of the society as a whole (Article 4 [4]); allow their participation in economic progress and development (Article 4[5]); consider the legitimate interests of minorities in developing and implementing national policies and programs, and international programs of cooperation and assistance (Article 5); cooperate with other States on issues regarding minorities, including exchanging information and experiences, to promote mutual understanding and confidence (Article 6); promote respect for the rights set forth in the Declaration (Article 7); fulfill the obligations and commitments States have assumed under international treaties and agreements to which they are parties (Article 8 [1] . Finally, the specialized agencies and other organizations of the United Nations system shall also contribute to the realization of the rights set forth in the Declaration (Article 9).

\section{Other Instruments}

The International Covenant on Economic, Social and Cultural Rights ${ }^{8}$ establishes the principle of non-discrimination, stating that: "the States Parties to the present Covenant undertake to guarantee that the rights enunciated in the present Covenant will be exercised without discrimination of any kind as to race, color, sex, language, religion, political or other opinion, national or social origin, property, birth or other status." In this respect, General Comment num. 14 (2000) of the Committee on Economic, Social and Cultural Rights, on the right to the highest attainable standard of health, explains that health facilities, goods and services must be within safe physical reach for all sections of the population,

8 International Covenant on Economic, Social and Cultural Rights, Dec. 16, 1966, GA Res. 2200A (XXI), article 2.2. 
especially vulnerable or marginalized groups, including ethnic minorities. ${ }^{9}$ Furthermore, all health facilities, goods and services must be culturally appropriate, for instance respectful of the culture of minorities. In this sense, the Committee says that: "States are under the obligation to respect the right to health by, inter alia, refraining from denying or limiting equal access for all persons, including [...] minorities, to preventive, curative and palliative health services." ${ }^{\prime 10}$

Similarly, the International Convention on the Elimination of all Forms of Racial Discrimination" defines "discrimination" as "any distinction, exclusion, restriction or preference based on race, color, descent, or national or ethnic origin which has the purpose or effect of nullifying or impairing the recognition, enjoyment or exercise, on an equal footing, of human rights and fundamental freedoms in the political, economic, social, cultural or any other field of public life." That is, it prohibits any exclusion of human rights based on race, national or ethnic origin (among others), thus protecting minorities in which immigrants are included.

The Convention on the Rights of the Child" provides that "in those States in which ethnic, religious or linguistic minorities or persons of indigenous origin exist, a child belonging to such a minority or who is indigenous shall not be denied the right, in community with other members of his or her group, to enjoy his or her own culture, to profess and practice his or her own religion, or to use his or her own language." In other words, the convention protects children belonging to minorities and their rights to practice and enjoy their group's religion, language and culture.

The International Convention on the Protection of the Rights of all Migrant Workers and Members of their Families ${ }^{13}$ defines the principle of non-discrimination in the following terms: "the present Convention is applicable [...] to all migrant workers and members of their families without distinction of any kind such as sex, race, color, language, religion or conviction, political or other opinion, national, ethnic or social origin, nationality, age, economic position, property, marital status, birth or other status." That is, it prohibits any exclusion of human rights based on the reasons mentioned above. Additionally, Article 31 protects the cultural identity of all migrant workers and their families on stipulating that: "States Parties shall ensure respect for the cultural identity of migrant workers and members of their families and shall not prevent them from maintaining their cultural links with their State of origin."

9 UN Committee on Economic, Social and Cultural Rights, General comment num. 14 on the right to the highest attainable standard of health, UN Doc E/C.12/2000/4, (2000), par. 12.

10 Id., par. 34.

11 International Convention on the Elimination of all Forms of Racial Discrimination, Dec. 21, 1965, GA Res. 2106 (XX), article 1.

12 Convention on the Rights of the Child, Nov. 20, 1989, GA Res. 44/25, article 30.

13 International Convention on the Protection of the Rights of all Migrant Workers and Members of their Families, Dec. 18, 1990, GA Res. 45/158, article 1. 
The Basic Principles and Guidelines on the Right to a Remedy and Reparation for Victims of Gross Violations of International Human Rights Law and Serious Violations of International Humanitarian Law ${ }^{14}$ state that restitution to the victim includes, as appropriate: "restoration of liberty, enjoyment of human rights, identity, family life and citizenship, return to one's place of residence, restoration of employment and return of property." This principle could be broadly interpreted as to include the right to have one's status as indigenous person or person belonging to a minority restored, in particular where this is provided for under national legislation and if such status is lost as a consequence of displacement.

The Convention on the Prevention and Punishment of the Crime of Genocide ${ }^{15}$ is a legal source referred to in the United Nations Minorities Declaration for protecting the rights of minorities as it protects groups, including minorities, and their right to physical existence. It defines genocide as

any of the following acts committed with intent to destroy, in whole or in part, a national, ethnical, racial or religious group, as such: killing members of the group; causing serious bodily or mental harm to members of the group; deliberately inflicting on the group conditions of life calculated to bring about its physical destruction in whole or in part; imposing measures intended to prevent births within the group; forcibly transferring children of the group to another group.

The Rome Statute of the International Criminal Court ${ }^{16}$ provides for the prosecution of cases that encompass not only the crime of genocide but also crimes against humanity, in which forced population transfers intended to move persons belonging to minorities away from the territory on which they live (or with that effect) is included.

The ILO Discrimination (Employment and Occupation) Convention (Num. 111) ${ }^{17}$ requires States to adopt and implement national policies to promote and ensure equality of opportunity and treatment in employment and occupation, with a view to eliminating direct and indirect discrimination on grounds of race, color, sex, religion, political opinion, national extraction or social origin. These national policies must address discrimination and promote equality, in law and in practice, regarding access to education and training, employment

14 Basic Principles and Guidelines on the Right to a Remedy and Reparation for Victims of Gross Violations of International Human Rights Law and Serious Violations of International Humanitarian Law, Dec. 16, 2005, GA Res. 60/147.

15 Convention on the Prevention and Punishment of the Crime of Genocide, Dec. 9, 1948, GA Res. 260 A (III), article 2.

16 Rome Statute of the International Criminal Court, Jul. 17, 1998, U.N. Doc. A/ CONF.183/9*, article 7 .

17 ILO Discrimination (Employment and Occupation) Convention, 1958 (num. 111), Jun. 25, 1958, articles 1-2. 
services, recruitment, access to particular occupations, as well as terms and conditions of employment.

The ILO Declaration on Fundamental Principles and Rights at Work ${ }^{18}$ provides that all members of the Organization have an obligation to respect, promote and realize the fundamental principles and rights at work ("core labor standards.") These include the principle of non-discrimination in employment and occupation, freedom of association and the right to collective bargaining, and the elimination of forced and compulsory labor, as well as child labor. The enjoyment of equality of opportunity and the treatment of minorities are monitored under this Declaration.

The Convention for the Safeguarding of the Intangible Cultural Heritage ${ }^{19}$ provides safeguards and promotes the practices, representations, expressions, knowledge, skills — as well as the associated instruments, objects, artefacts and cultural spaces - that communities, groups and, in some cases, individuals recognize as part of their cultural heritage. For this purpose, the Convention establishes a fund and a listing system of the heritage that is representative and in danger.

The Convention on the Protection and Promotion of the Diversity of Cultural Expressions $^{20}$ encourages States to incorporate culture as a strategic element in national and international development policies and to adopt measures aimed at protecting and promoting the diversity of cultural expressions within their territory. It emphasizes the importance of the recognition of equal dignity and respect for all cultures, including that of persons belonging to minorities, and of the freedom to create, produce, disseminate, distribute and have access to traditional cultural expressions, and asks States to endeavor to create environments conducive thereto.

In addition, several regional human rights treaties include provisions that can be invoked to advance minority rights. The Council of Europe's Framework Convention for the Protection of National Minorities contains particularly detailed provisions on minority rights in various fields.

\section{Minority Rights for Immigrants}

By bearing or adhering to a distinct ethnicity, race, or religion, immigrants constitute a minority group in the society into which they move, ${ }^{21}$ and they should be afforded the corresponding rights, in community with the other

\footnotetext{
18 ILO Declaration on Fundamental Principles and Rights at Work, Jun. 18, 1998.

19 Convention for the Safeguarding of the Intangible Cultural Heritage, Oct. 17, 2003, Articles 25-28.

20 Convention on the Protection and Promotion of the Diversity of Cultural Expressions, Oct. 20, 2005.

21 See Christian Joppke, Minority Rights for Immigrants? Multiculturalism versus Antidiscrimination, 43 Isr. Law Rev, (2010).
} 
members of their group, to enjoy their own culture, to profess and practice their own religion, or to use their own language. ${ }^{22}$ However, the application of minority international standards to this group is not as clear as one would think. Part of this difficulty derives from the absence of a definition of "minority." Actually, the controversy on the definition of this concept over the years prompted some scholars to doubt the relevance of having any such definition. ${ }^{23}$ On the contrary, other scholars took a different position on the issue arguing that the proper application of the international standards on minority rights requires a clear conceptualization of the notion of minority. ${ }^{24}$ However, the official position of the UN supports the first opinion. The Working Group established to draft the Declaration stated that: "the Declaration could function perfectly well without precisely defining the term as it was clear [...] to which groups the term referred to in concrete cases." ${ }^{\prime 25}$

Because of the lack of a widely accepted definition, some scholars maintain that the term 'minority' applies only to nationals of a State for the reason that non-nationals are protected by customary international law. ${ }^{26}$ However, it is not well defined why their application should be limited to nationals only. The formulation of Article 27 of the ICCPR does actually not make a distinction between nationals and foreigners. What it requires is that State Parties refrain from denying minorities the right to enjoy their culture, to profess their religion or to use their own language. ${ }^{27}$ In addition, the grammatical interpretation of the article suggests that the reference to "persons" as opposed to "nationals" or "citizens," as in Article 25 of the ICCPR (political rights), is meant to apply both to nationals and non-nationals. ${ }^{28}$ Finally, systematic reading of the text of the ICGPR also leads to the same conclusion. As a general rule, under Article 2 States Parties to ICCPR are obliged to guaran-

22 See International Covenant on Civil and Political Rights article 25, Dec. 16, 1966, GA Res. 2200A (XXI), Article 27.

23 See P. Thornberry, International law and the rights of minorities (Clarendon Press, 1991); H. Hannum, Contemporary developments in the international protection of the rights of minorities, 66 Notre Dame Law Rev., (1991); G. Alfredsson \& A. De Zayas, Minority rights: Protection by the United Nations, 14 HRLJ 1-2, (1993); Francesco Capotorti, Study on the rights of Persons BELONGING TO ETHNIC, RELIGIOUS, AND LINGUISTIC MINORITIES, (UN 1991).

24 See M. N. Shaw, The definition of minorities in international law, 20 IYHR, (1991); M. NowAK, Un Covenant on Civil and Political Rights. CCPR Commentary (Engel, 1993); J. Packer, On the content of minority rights, in Do WE NEED MINORITY Rights?-CONCEPTUAL Issues (J. Räikkä ed., 1996).

25 UN Commission on Human Rights, Report of the Working Group on the Rights of Persons belonging to National, Ethnic, Religious and Linguistic Minorities, UN Doc. E/CN.4/1991/53 (5 March 1991), par. 9.

26 Francesco Capotorti, supra note 23.

27 UN Human Rights Committee, General Comment num. 23: The rights of minorities (Article 27), UN Doc GGPR/C/21/Rev.1/Add.5, (1994), par. 5.2.

28 M. Nowak, UN Govenant on Givil and Political Rights. GCPR Commentary 489 (Engel, 1993). 
tee the rights in the ICGPR to all persons under their jurisdiction without distinction as to, inter alia, nationality. Exceptions to this rule must be made expressly as in the case of Article 13 (only for aliens) and Article 25 (only for citizens). In the absence of such express special provision, all rights under the Covenant, including those under Article 27, are available to non-nationals in as much as to nationals. This is also the interpretation of the Human Rights Committee that in its General Comment No. 23 says that: persons who are not citizens of the country in which they reside can form part of or belong to a minority in that country. ${ }^{29}$

Regarding this issue, the Working Group on Minorities affirmed that: "citizenship as such should not be a distinguishing criterion that excludes some persons or groups from enjoying minority rights under the Declaration." 30 However, it also said that other factors can be relevant in distinguishing between the rights that can be demanded by different minorities, i. e., "«old» minorities have stronger entitlements than the «new.»" are some scholars who wish to limit the application of minority rights to groups with established ties with the State. For example, Nowak maintains that immigrants, including migrant workers, can be able to claim the protection of Article 27, but only after a certain (long) period of residency in the State. ${ }^{32}$ And Thornberry criticizes the Human Rights Committee position in that even visitors are entitled to the rights under Article 27. ${ }^{33}$ Nevertheless, as far as the narrowly defined basic minority rights are concerned, it is not clear why, as the Human Rights Committee observed, migrant workers or even visitors to a State Party constituting minority groups should be denied the rights to enjoy their culture, to profess their religion and to use their own language.$^{34}$ It is not therefore appropriate to generally conclude that the concept minority ordinarily exclude non-nationals.

In practice, under international law, certain minority rights have been made applicable to recently arrived migrants who share an ethnic, religious or linguistic identity. Their treatment is to be rooted in the customary international law principle of non-discrimination, which is fundamental in international law and is reflected in all human rights instruments and documents. Indeed, the

29 UN Human Rights Committee, General Comment num. 23: The rights of minorities (Art. 27), UN Doc CGPR/C/21/Rev.1/Add.5, (1994), par. 5.1, 5.2.

30 UN Commission on Human Rights, Commentary of the Working Group on Minorities to the United Nations Declaration on the rights of persons belonging to national or ethnic, religious and linguistic minorities, UN Doc E/CN.4/Sub.2/AC.5/2005/2, (2005), par. 10.

31 Id., par. 11.

32 M. NowAK, supra note 28.

33 P. Thornberry, The UN Declaration on the rights of Persons Belonging to National or Ethnic, religious and Linguistic Minorities: Background, analysis, observations and an update, in UNIVERSAL MINORITY Rights 32 (A. Phillips \& A. Rosas eds., 1995).

34 UN Human Rights Committee, General Comment num. 23 (50) (article 27), UN Doc CCPR/C/21/Rev.1/Add.5, (1994). 
right not to be discriminated against is guaranteed under several instruments of universal acceptance (as the Covenants on Civil and Political Rights and on Economic, Social and Cultural Rights) and others of direct relevance to minorities, such as the International Convention on the Protection of the Rights of All Migrant Workers and Members of Their Families, the Convention relating to the Status of Stateless Persons, the Convention relating to the Status of Refugees, and the Declaration on the Human Rights of Individuals Who are not Nationals of the Country in which They Live.

In sum, it can be said that minority rights are applicable to immigrants, not only because they are not explicitly excluded from their protection, but also because the Declaration and the Covenant are inspired by the principles of universality and non-discrimination, as well as the rest of the human rights covenants. In international human rights law, the primary concern is the protection and promotion of universal human rights. These rights - which include minority rights - are entitlements that pertain to all human beings at all times irrespective of their particular circumstance, such as the nationality in the case of immigrants. Human rights are inherent in human nature and thus constitute "the birthrights of all human beings." 35 That is the reason why human rights are normally cast in universal terms entitling all human beings to the same rights and protections. The terms used in proclaiming human rights in international instruments such as "all human beings," "everyone," "no one" bespeaks the universal character of human rights.

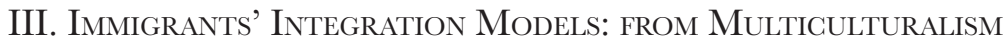 to Givic Participation}

In this section we will analyze the immigrants' integration models of Canada, the Netherlands and the United States, as they most clearly illustrate the different positions that integration programs have assumed, i. e., multiculturalism, state liberal integrationism, and civic integration (or participation). The approach of this section is in the form of "historical institutionalism," 36 integrating sociological insights of political aspects present in the societies of the countries mentioned above over time. The analysis takes place within a liberal democratic framework as democratic-egalitarian ideals are strongly held and incorporated in the immigrant integration projects of these nations. The analysis is limited to a timeframe that dates back to the end of the Second World War, as it is considered that immigration programs were more in-

35 UN General Assembly, Vienna Declaration and Programme of Action, UN Doc. A/ CONF.157/23, (12 July 1993).

36 T. Skocpol, Why I Am an Historical Institutionalist, 28 PoLITy 1, (1995). 
stitutionalized and enforced at that time when "modern" nation-States began to formally establish themselves. ${ }^{37}$

The policies and orientation of immigration measures in the post-war period are characterized as being "broadly if imperfectly inclusive." 38 The human rights influence on legal national and international regimes and discourses, "extended rights from national citizens to all 'persons' irrespective of citizenship." 39 For some countries these principles still stand as core elements of immigration and integration projects. Nevertheless, the presence of ethnic, cultural, and political elements (namely nationalisms) make immigration a matter of ethnic and cultural identities and citizenship. Additionally, while low-skilled labor still is economically required by a group of countries, so as to supply their services and unskilled labor markets, the irregular influx of immigrants that fill such market gaps has turned immigration into a political, social, and identitarian issue that strongly contends and emphasizes the provision of rights. Finally, due to a status-based conception of rights and recognition provision from the part of the State, citizenship has become the gold standard and ultimate objective for immigrants to achieve as:

In Most Countries some set of rights and benefits are reserved to people who possess that country's citizenship status. This means that individuals who lack citizenship status (who are designated by law as "aliens") are denied the full enjoyment of social, political, and civil rights in the receiving society, at least for some period. People differ on the question of how accessible citizenship status should be in the first instance, but most agree that, once acquired, possession of citizenship status should be legally consequential for some purposes. ${ }^{40}$

Here, the extensive/inclusive nature of national (and international) postwar legal regimes comes into play so as to provide non-citizens with "important procedural rights that serve to constrain state power over them [...]." Such protection is in no way equal, substantial and/or always available to all classes of immigrants, as there are various categorizations that differ in the rights that they convey. The most common instance in which immigrants are

37 See Irene Bloemraad, Begoming a citizen: Incorporating Immigrants and Refugees In the United States and Canada (University of California Press 2006); Stephen Gastles \& Mark J. Miller, The age of migration: international population movements in the MOdern wOrLd (Palgrave Macmillan 2009); J. F. I. Klaver \& A. W. M. Odé, Givic Integration and Modern Citizenship: The Netherlands in Perspective (Europa Law Pub, 2009).

38 Gary Freeman, Incorporating Immigrants in Liberal Democracies, 03-09 CMD WORKING PAPER 3, (2003).

39 Christian Joppke, Immigrants and Civic Integration in Western Europe, in BeLOngING? Diversity, Recognition and Shared Gitizenship in Canada 3 (K. Banting et al., eds., 2007).

40 Linda S. Bosniak, Being here: Ethical Territoriality and the Rights of Immigrants, 8 THEORETICAL INQ L 2, 37 (2007).

41 Id., 34. 
deprived of rights is when they are deemed criminals due to irregular immigration status. The criminalization of immigrants is a phenomenon that has evolved from a civil or administrative matter to a penal one as more and more of immigrants' activities and/or forms of entering and residing in the receiving countries have been defined as (aggravated) felonies. ${ }^{42}$

A variety of issues emerge here since immigrants' rights depend on their status, $i$. e. citizenship (or the different gradients of it) or immigration status. As Bosniak acknowledges, there are ongoing discussions about important aspects of citizenship:

In addition to issues involving the allocation and distribution of status citizenship, scholars have devoted substantial attention to questions about the legal significance of the status. The inquiry here is what, exactly possession or lack of possession of citizenship status should rightfully entail within a national society. Because citizenship is an exclusive status, and because in most States foreigners enter the territory in status short of citizenship, the question arises as to how those without citizenship status should be treated. To what extent should enjoyment of basic rights depend on being a status citizen, and to what extent should it depend on the fact that personhood and territorial presence alone? ${ }^{43}$

Citizenship, and the many variants it may present, seems to be at the core of the discussion about the incorporation of immigrants. However, as an often indistinguishable feature amongst immigrants and other members of society, it is not the purpose of this section to articulate in depth the constraints and benefits citizenship represents, but rather to focus on the programs and policies implemented by liberal democratic governments in order to integrate immigrants to their societies, and ultimately make them citizens who fully enjoy and practice their social, political and civil rights.

\section{Multiculturalism}

There are different approaches found in academic literature that define what multiculturalism is in contextual terms, namely accommodation/toler-

42 See Bill Ong Hing, Immigrant as Criminal: Punishing Dreamers, 9 Hastings Women’s L.J. 1, (1998); Daniel Kanstroom, Immigration Law as Social Control: How Many People Does it take to Make you Feel Secure?, in Civil Penalties, Social Consequences (C. Mele \& T.A. Miller eds., 2005); T. Miller, Citizenship and Severity: Recent Immigration Reforms and the New Penology, 17 Georget ImmgR Law J. 4, (2003); J. Simon, Governing through crime: How the War on Crime Transformed american Democracy and Created a Culture of Fear (Oxford University Press, 2007); J. A. Warner, The Social Construction of the Criminal Alien in Immigration Lawe, Enforcement Practice and Statistical Enumeration: Consequences for Immigrant Stereotyping, 1 JourNaL OF SOCIAL AND ECOLOGICAL BOUNDARIES 2, (2005).

43 Linda S. Bosniak, supra note 40. 
ance of differences. However, very few state a definition that can be used as a cohesive one, be it for research purposes or policy making and implementation. Kymlicka states that multiculturalism means "Canada's approach to the accommodation of groups formed by immigration." ${ }^{44}$ In a more comprehensive political context, multiculturalism reflects the longer experience settler societies have had "with an intentional strategy of diversity planning and management of nation-building within which immigration is a fundamental cornerstone. ${ }^{\prime 45}$ Both the United States and Canada share this strategy, as they also share common British roots. Notwithstanding, their trajectories departed along the way, making each country's national project ${ }^{46}$ differ due to the categories and principles they are based upon.

\section{A. Canadian Multiculturalism}

The conformation of the Canadian nation is the result of some "polite revolts against British tutelage" ${ }^{47}$ that, through a series of Naturalization Acts and imperial statutes, determined the routes to citizenship in Canada. There was, however, room for discretionary practices in the granting of naturalization, which allowed for a variety of membership classes. In the post-World War II era, some political and legislative measures were taken in order to make membership in Canada more equitable and as a means to assert its sovereignty and national identity. ${ }^{48}$ The latter combined with the emergent discussions on cultural relativism and ethnocentric notions and the American Civil Rights movements at the end of 1950s and early 1960s. "As a result of all this, by the mid-1950s the idea of assimilation was replaced in official government thinking by the notion of integration in which some recognition of the cultural identity of immigrants was seen as beneficial in creating national unity." ${ }^{\prime 9}$ Nonetheless, British culture was dominant in Canada and its immigration practices excluded non-European immigrants. This situation

44 William KyMlicka, Finding OUR WAY: RETHINKING ETHNOCUltural RELATIONs IN CANADA 8 (Oxford University Press, 2004).

45 D. Ley, Multiculturalism: A Canadian Defense, 07-04 MBC WORKInG PAPER, 3 (2007).

46 We use the concept of "national project" with some reserve, as there is an ongoing discussion where Joppke (2007) asserts that multiculturalism, or any other integration project may not refer to nation-building projects as the global and strategic mobility and malleability of borders do not allow us to talk about nations anymore. Such position is contended by authors such as Jacobs and Rea (2007), who think that the nation-state still remains as a category, and an empirical legal, social, political and economic reality. See Christian Joppke, Beyond national models: Civic integration policies for immigrants in Western Europe, 30 WEST EUR POLIT 1, (2007); D. Jacobs \& A. Rea, The end of national models?' Integration courses and citizenship trajectories in Europe, 9 IJMS 2, (2007).

47 Irene BloemraAd, supra note 37.

48 Id.

49 J. F. I. KLAVER \& A. W. M. Odé, supra note 37. 
allowed the assumption that newcomers' assimilation into "Canada's culture' would not present a challenge as they were «culturally homogeneous.»" ${ }^{\text {" Dif- }}$ ferences, whether formally recognized, were not welcomed.

By early 1970s Canada introduced the concept of multiculturalism. Although it was, to some extent, an unintended consequence of the 1960s clashes between Anglo and Francophone populations, which - in the process of accommodating their demands - made evident that "citizens outside these «charter groups» accounted for 25 per cent of the national population and immigration trends [...]." ${ }^{51}$ Thus, policies and new governmental orientation had to further meet the needs of non-British European immigrant groups and their descendants. ${ }^{52}$ Policies for the sake of politics were closer to meet.

From then onwards, multiculturalism was set as a public policy in Canada, granting State action to enforce the protection of equal rights for minorities. $^{53}$ This can be illustrated by the various pieces of legislation that were passed and are at the core of the Canadian immigration system. One of the cornerstones of the more universalistic and liberal policies implemented was the Canadian Bill of Rights in 1960 where "discrimination based on race, color, national origin, religion, or sex was rejected." ${ }^{" 54}$ In 1967, a point system that supported the assumed non-discriminatory policy of the 1960 Bill was introduced. ${ }^{55}$

Currently, Canadian immigration system follows three main objectives: "to reunite families, to fulfil the country's international obligations and humanitarian tradition with respect to refugees, and to foster a strong and viable economy in all regions of Canada. ${ }^{\prime 56}$ The provision of rights to immigrants is built upon a territorial based standing, as all provisions in the 1982 Canadian Charter of Rights and Freedoms "[w] ith the exception of the right to vote, some mobility rights and minority language education rights [...] apply to any person within Canada, meaning that also non-citizens are guaranteed these fundamental civic and political citizenship rights. ${ }^{, 57}$

Canada's multiculturalism strives for instituting a Canadian citizenship over diverse national identities in order to keep democratic liberal values at the core of societal and identitarian practices. Specific cultural features

50 Irene Bloemraad, supra note 37; Stephen Castles \& Mark J. Miller, supra note 37; J. F. I. KLAVER \& A. W. M. ODÉ, supra note 37.

51 D. Ley, Multiculturalism: A Canadian Defense, 07-04 MBC WORKInG PAPER, 4 (2007).

52 J. F. I. Klaver \& A. W. M. Odé, supra note 37.

53 Stephen Castles \& Mark J. Miller, supra note 37.

54 J. F. I. KLAVER \& A. W. M. Odé, supra note 37.

55 The neutrality of this points system has been contended, as it is a form of selection that has as an underlying principle of exclusion. For further discussion on the topic see: J. F. I. Klaver \& A. W. M. Odé, supra note 37; A. Simmons, Immigration and Canada: Global and Transnational Perspectives (Canadian Scholars' Press, 2010).

56 J. F. I. KLAVER \& A. W. M. Odé, supra note 37.

57 Id, 142. 
are preferred as private or diversity and "artistic" (folkloric) practices. In this sense, integration to mainstream society implies a quasi-acculturation, or as Joppke calls it "de-ethnicization." ${ }^{58}$ On top of the latter, language has been a major barrier for immigrants' incorporation to the labor market as the point system for selection in place only requires minimum conversational skills that may not be suitable for work environments. ${ }^{59}$ Credentialization is another major issue in the participation of immigrants in the workforce as Canada and the countries of origin (emerging economies for the most) have different educational systems - incommensurable according to Canada's standardswhich precludes immigrants from taking positions they are certified for back in their countries and profit from it economically or for status improvement. ${ }^{60}$ Lastly, family reunification -as the main category of immigration- means a gap in Canada's selection point system, as the qualifications of family members are not as strictly enforced as they are with the main immigrant member. ${ }^{61}$ Thus, in spite of Canada's best efforts, $i$. e. involvement, support, sponsorship and implementation and enforcement of policies, the integration of immigrants has not reached the desired levels.

\section{B. US Multiculturalism}

American citizenship is the result of its revolution of independence. At that point in time, many of the shared characteristics with Canada parted different ways, and membership (and its restrictions) legitimized the "new State." ${ }^{62}$ In the case of the United States, restrictions seem more consequential for the analysis, as from the beginning:

American citizenship contained important limits to its inclusive vision [...] [G]itizenship in the United States had a strong tendency to "ascriptive Americanism:" legal statutes, judicial decisions, and legislative debates 'manifested passionate beliefs that America was by rights a white nation, a Protestant nation, a nations in which true Americans were native-born men with Anglo-Saxon ancestors. ${ }^{63}$

\footnotetext{
58 Christian Joppke, Citizenship between De- and Re-Ethnicization, 44 Arch Eur Sociol, (2003).

59 J. F. I. Klaver \& A. W. M. Odé, Givic Integration and Modern Citizenship: The Netherlands in Perspective 142 (Europa Law Pub, 2009).

60 Irene Bloemraad, supra note 37; Stephen Castles \& Mark J. Miller, supra note 37; J. F. I. KLAVER \& A. W. M. OdÉ, supra note 37; A. Simmons, supra note 55.

61 Stephen Castles \& Mark J. Miller, supra note 37; J. F. I. Klaver \& A. W. M. Odé, supra note 37.

62 Irene Bloemraad, supra note 37.

63 Id., 21.
} 
Citizenship in the United States has always been closely linked to migration, and strongly limited by race. Thus, a series of policies and laws have regulated immigrants since its independence. In spite of that, it was not until after the World War II that the country saw the consolidation of "previous immigration laws into a statute which is still the foundation of immigration law today." "64 This piece of legislation is the Immigration and Nationality Act of 1952 (INA). In the Act, as in the pre- and post-immigration Acts, a key characteristic is its reactiveness, $i$. e. "immigration policy in the United States history evolved as a response to a series of crisis, each prompting a redefinition of the qualifications for membership and an elaboration of the instruments to further restrict new immigration." ${ }^{\prime \prime 5}$ A quota system was first implemented and Western European immigration was privileged over other nationalities. This policy was first passed in 1921, but was abolished in 1965 . Such change responded to unfavorable (and unwanted) consequences of the visa quotas allocation numbers that eventually allowed the entrance of a large number of Asians, and increased unauthorized Mexican migration "changing the face of America." 66 The features of the population started to change along the lines of these groups of immigrants and their descendants, prompting a new policy response by the mid-1980s. In 1986, the Immigrant Responsibility and Control Act (IRCA) was passed. It emphasized measures for restricting the entrance of irregular immigrants which included sanctions to employers, the legalization of a large number of irregular immigrants and the implementation of "a far reaching anti-discrimination provision, prohibiting employment discrimination on the basis of citizenship. ${ }^{\prime 67}$ Hardly any of the enforcement objectives were reached, but up to three million immigrants regularized their status.

Irregular immigration to the United States became a major socio-political concern as economy fluctuated. In 1996, the government tried to tackle the increasing numbers of immigrants by passing the Illegal Immigration Reform and Immigration Responsibility Act (IIRIRA). The United States government took a number of additional measures in order to discourage, control, and punish irregular migrants, but these measures and policies relate to the penal system. Importantly, the immigration system and the penal systems have collided so as to result in what Stumpf ${ }^{68}$ has called crimmigration. ${ }^{69} \mathrm{In}$

\footnotetext{
64 J. F. I. KLAVER \& A. W. M. OdÉ, supra note 37.

65 Id.
}

66 Bill Ong Hing, Deporting Our Souls: Values, Morality, and Immigration Policy (Cambridge University Press 2006); P. L. Martin, The United States: The Continuing Immigration Debate, in Controlling Immigration: A Global Perspective (Wayne A. Cornelius et. al. eds., 2004).

67 J. F. I. KLaver \& A. W. M. Odé, supra note 37.

68 Juliet P. Stumpf, The Crimmigration Crisis: Immigrants, Crime, and Sovereign Power, $56 \mathrm{Am} \mathrm{U}$ L Rev., (2006).

69 For more on Crimmigration, see Bill Ong Hing, supra note 42; Daniel Kanstroom, 
counter position, the United States government is not focused on implementing policies that improve immigrants' integration. As Klaver and Odé assert:

Nowadays, the reluctance of federal governments in the US to deal with social and collective problems has become highly apparent in the scanty public support for the development of a welfare state. McCluskey (2003) concludes that this is related to the liberal and neo-liberal ideological dominance in the US, and the belief that social well-being flows from an unimpeded private pursuit of individual preferences and interests, rather than from government enforcement of moral ideals [...] emphasis on individual contract and property rights in the American tradition relegates other relations to a less esteemed status and restricts the emergence of alternative social citizenship rights. ${ }^{70}$

This is US political multiculturalism. ${ }^{71}$ It is based on racial differentiation and as a result, hyphenated citizenships (namely Mexican-American) as parts of the identity of individuals that only represent a shade of the black-white color continuum, $i$. e. brown, when related to the public political arena. This element facilitates or precludes integration and/or incorporation of immigrants to certain spheres of the public and private sectors. The case of the United States shows that liberal democratic States that limit their participation in the integration of immigrants grant a 'thin citizenship', i. e., "citizenship-asstatus-«mere status.»"

Nevertheless, United States constitutional rights theoretically apply to all immigrants, citizens and non-citizens, including - to a certain extent - irregular immigrants. The reach of the protection depends upon duration of residence, and legal status, but some basic civil rights are granted to irregular immigrants, as they would be with citizens. ${ }^{73}$ It is necessary to bring to the fore the fact that United States government provides some support (i. e. material assistance) to refugees, making them less prone to vulnerability. Immigrants who only hold a race-based economic citizenship (or are irregular) in the United States do not have access to this type of assistance. ${ }^{74}$

\footnotetext{
supra note 42; T. Miller, supra note 42; J. Simon, Governing through Crime: How the War on Crime Transformed American Democracy and Created a Culture of Fear (Oxford University Press, 2007); J. A. Warner, supra note 42.

70 J. F. I. KLAVER \& A. W. M. OdÉ, supra note 37.

71 Irene BloemraAd, supra note 37.

72 Linda S. Bosniak, supra note 40.

73 J. F. I. KLAVER \& A. W. M. OdÉ, supra note 37.

74 Irene BloemraAd, supra note 37.
} 
Esta revista forma parte del acervo de la Biblioteca Jurídica Virtual del Instituto de Investigaciones Jurídicas de la UNAM www.juridicas.unam.mx

\section{Civic Integration and Citizenship Trajectories}

As we have seen so far, immigration policies and immigrants' integration to new societies poses a series of challenges for governments, as they try to attain specific objectives that for the most, rely on immigration "as a tool for population and economic expansion." "75 However, integration has become a very unstable ground in Europe as "the meaning and practice of multiculturalism in Western Europe is a unifying sense of unease, and periodic crisis in assessing the failure of immigrant and refugee inclusion." 76 Thus, some countries that used to be oriented and committed to the integration of immigrants into their societies have now steered away from multiculturalism and cultural pluralism policies in order to get closer to their integration objectives. The new formats for integration require immigrants to actively participate in their own immersion into the culture, language and labor market of the receiving country. There is, as a result, a "citizenship trajectory" 77 they must complete in order to be able to fully access the rights and benefits citizenship implies.

The Netherlands is one of these countries and is now implementing a new model for integration that in essence opposes multiculturalism. As it is now, the Dutch system is considered the most coercive immigration system, ${ }^{78}$ one that is not only enforced territorially, but has expanded its boundaries (read barriers) extra-territorially. ${ }^{79}$

\section{The Dutch Civic Participation Integration Program}

The Dutch immigration system was less complex in the past, as Vink asserts:

For most of the post-war period, no explicit government policy existed in the Netherlands to deal comprehensively with the legal status and social integration of these newcomers. The main reason for this tacit approach was that repatriates from former colonies, apart from an emergent need for housing upon their arrival, were assumed to have no difficulties with integration in Dutch society, and "guest workers" were

75 Id., 18.

76 D. Ley, Multiculturalism: A Canadian Defense, 07-04 MBC WORKInG PAPER, 3 (2007).

77 We borrow the term from Jacobs and Rea (2007) in their discussion of integration courses and "other stages", i. e. citizenship trajectories, to attain citizenship. See D. Jacobs \& A. Rea, The end of national models? Integration courses and citizenship trajectories in Europe, 9 IJMS 2, (2007).

78 Irene Bloemraad, supra note 37; J. F. I. Klaver \& A. W. M. Odé, supra note 37; M. P. Vink, Dutch 'multiculturalism' beyond the pillarisation myth, 5 Polit. Stud. Rev 3, (2007).

79 Irene Bloemradd, supra note 37; Christian Joppke, Minority Rights for Immigrants? Multiculturalism versus Antidiscrimination, 43 IsR. LAW REv, (2010). 
assumed to return to their countries of origin after a few years working in the Netherlands. This resulted in a rather ad hoc way of dealing with immigrants. ${ }^{80}$

However, by 1979, several Dutch institutional reports came up to the conclusion that the government had to come to terms with the fact that it had become an immigration country. As a result, in 1983 a new minorities policy was implemented (the 1983 Minorities Memorandum) whose approach "included a number of general provisions that related specifically to the legal status of immigrants, most notably with regard to political participation and citizenship status." ${ }^{\prime 1}$ The Dutch government held a tolerant position when it referred to dual citizenship so that the number of naturalizations and (assumedly) integrations would rise. This position coupled with the 1994 Equal Treatment Act - that targeted the educational and labor spheres - and the 1998 Act for Stimulation of Labour Market, with the intent of offering immigrants more proportionate access in order to improve their legal and socioeconomic statuses. The social aspect of such policies is an important feature to underline because it focused on "promoting the emancipation of ethnic communities in a broader social and cultural sense." 82

Notwithstanding, the different policies implemented by the Dutch government to ameliorate the effects of migration for specific ethnic (minority) groups, namely Turks and Moroccans:

[r]ather [were] pragmatic strateg[ies] aimed at preparing guest workers for return to their countries of origin, which would be facilitated by integrating foreign workers as little as possible into their temporary host society. Later on, when the idea of guest workers returning to their countries of origin became an increasingly unlikely scenario, the government's "ethnic minority" policy consisted indeed of a group-based approach to immigrants, but only for certain groups, and always in a strictly top-down, even condescending manner. Minority organizations needed to be supported in order to provide the government with clearly identifiable and hopefully, representative discussion partners. The process has been aptly coined as the "minorization of minorities." "83

Nowadays, the Netherlands - followed by several other Western European nations - has implemented the so-called 'civic integration' policies for targeted immigrant groups. Some of the measures taken for the civic integration of such groups include, but are not limited to: a) overseas integra-

80 M. P. Vink, Dutch 'multiculturalism' beyond the pillarisation myth, 5 PoLIT. Stud. Rev 3, 340 (2007).

81 Id.

82 Id., 341.

83 M. P. Vink, supra note 80. 
tion testing; b) civic integration exams for foreign nationals that, if failed, entail fines, differential access to welfare services and the conditioning of a secure residence status. ${ }^{84}$ Only those immigrants who are expected to settle are obliged to participate in this program, but as stated, it is not open to voluntary participation.

\section{Lessons learned}

The United States case shows us that the State has transcended the socialwelfare State to become a "post-social State," as Inda recognizes, one that is subjecting the individuals and associations in its territory to become their own risk managers. Individuals, companies, institutions, and the like are to manage their well-being and functioning. ${ }^{85}$ This entails what Rose ${ }^{86}$ calls "ethopolitics," i. e., the transformation of citizens, and inhabitants of the United States into "ethical/moral" individuals that conform to these new requirements. If we assume that this simply represents an adaption to new economic orientations, then we have to consider, as Inda suggests us to do, that "the figure of the prudential subject needs to be understood in relation to the antipode: the oft-racialized anti-citizen unable or reluctant to exercise responsible selfgovernment" since "what the responsibilizing imperatives of contemporary government have done is created a realm of abjection [...] in other words have produced a division between active citizens and anti-prudential, unethical subjects $[\ldots]$ the truly disadvantaged. ${ }^{\prime 87}$

The Netherlands has gone from a multicultural to a civic participation project. This shift from more amicable policies to almost zero tolerance may respond, nonetheless, to the assumption that government promotion of multiculturalism retards immigrants integration: "the more the social and political institutions of the host society accept and recognize ethnic differences, the less likely are immigrants to experience pressure, either formally or informally, to file for citizenship [...]."88 This may well be the case of Canada, where even a shift to give more leverage to human capital for immigration has not allowed the incorporation of immigrants to the labor markets. ${ }^{89}$ In a true

\footnotetext{
84 J. F. I. KLAVER \& A. W. M. Odé, supra note 37.

85 Jonathan Xavier Inda, Targeting Immigrants: Government, Technology, and Ethics (Wiley-Blackwell 2006).

86 N. Rose, Community, Citizenship, and the third Way, 43 Aм. Behav. Sci 9, (2000).

87 For more on this new orientation of neo-liberal governments, new prudentialism, and ethopolitics. See Jonathan Xavier Inda, supra note 85; N. Rose, Community, Citizenship, and the third Way, 43 Am. Behav. ScI 9, (2000).

88 Irene BloemraAD, supra note 37.

89 "Recent immigrant groups are much more likely to experience unemployment [...] 11 percent [...] A number of recent studies have found a considerable and sustained income difference between newcomers and the Canadian-born population [...] Equally disturbing,
} 
sense, immigrants in the Netherlands are expected to become independent at the time of arrival, and those who are already there and are not able to do so are subjected to different forms of punishment. ${ }^{90}$

It is at this point that revisiting one of the best-illustrated and empirically proven theories about immigration becomes pertinent. Portes and Rambaut stated that besides individuals' characteristics, namely age, education, occupational skills, wealth, and language proficiency, "the social environment that receives [immigrants], including the policies of the host government, the attitudes of the native population, and the presence and size of a co-ethnic community" are crucial to immigrants. ${ }^{91}$ If it is so, the transmutation of the Dutch immigration system raises the question of the underlying motifs.

A simplified justification would be the objective of a full integration of newcomers, as has been mentioned, but more complex explanations have risen so that some of the most recent measures taken by the Netherlands even suggest to some authors that there is a "low intensity ethnic cleansing" behind such programs, ${ }^{92}$ or at least an intent for the "de-ethnicization" of immigrants and the "re-ethnicization" of Dutch citizens abroad so as to culturally homogenize the citizenry of the country. ${ }^{93}$ The explanatory power of such propositions is out of the reach and aim of this article, but it seems important to at least put them forward as food for thought.

International human rights norms can empower citizens in democracies by creating new vocabularies for claim-making, as well as by opening new channels of mobilization for civil society actors who then become part of transnational networks of rights activism and hegemonic resistance (Keck and Sikkink, 1998). Human rights norms must become elements in the public culture of democratic peoples through their own processes of interpretation, articulation, and iteration. ${ }^{94}$

however, is the grown incidence of poverty among immigrant in Canada's largest cities." See B. Ray, Canada: Policy Changes and Integration Challenges in an increasingly Diverse Society, MPI CounTrY PROFILES, (2005).

90 We talk about punishment because it is the result of a non-compliance with "laws" and because for immigrants struggling to gain stability, either economic fines or the conditioning of their legal status in the country is more of a punishment than an incentive.

91 A. Portes \& R. G. Rumbaut, Legacies: The Story of the Immigrant Second Generation 771 (University of California Press, 2001).

92 P. Mutsaers \& H.G. Siebers, Low intensity ethnic cleansing in The Netherlands, 38 TILBURG Papers in Culture Studies, (2012).

93 Christian Joppke, supra note 58.

94 S. Benhabib, Claiming Rights across Borders: International Human Rights and Democratic Sovereignty, 103 Am. Poltт. Sci. Rev. 4, 696 (2009). 


\section{Conclusions}

As Taylor ${ }^{95}$ has pointed out, a human being's identity is partly molded by recognition or its absence, often by the misrecognition of others, and so a person or group of people can suffer real damage, real distortion, if the people or society around them mirror back a confining or demeaning or contemptible picture of themselves. Non-recognition or misrecognition can inflict harm, can be a form of oppression, imprisoning someone in a false, distorted, and reduced mode of being.

Looking at the rights of minorities in international law, one finds that one of the most important justifications for ascription of rights to minorities is the aim of ensuring substantive justice to all members of society through genuine equality and non-discrimination. The most important effect of these provisions is that States are expected to pursue a policy that embraces the full diversity of their cultural components. Recognition and protection of the rights of minorities is indubitably an effective mode of accommodating the interests of minority groups, such as immigrants, in society.

However, in the immigration arena we have seen how different historical periods have evoked a series of specific immigration and integration policies that have limited or expanded immigrants' access to the political, civil, and social realms of mainstream society. Diverse positions on the accessibility to citizenship or other statuses feed back to the political arena, influencing policies and implementation that ultimately turn the access to and "contents" of citizenship into a controversial source of exclusion/inclusion. Here a differential status - in what Bosniak ${ }^{96}$ describes as a linear or concentric circles system of citizenship - may play and important part because the advancement towards a full citizenship status presumes and requires governments recognition and consent, thus establishing stronger bonds and making both individuals and governments responsible for certain minimum obligations.

Culture has become a proxy for race in immigration policy, becoming a source for exclusion. Additionally, the criminalization of immigrants and immigration has turned into a new form of social control and a rationale for exceptionalism when providing/granting basic rights to immigrants. None of the main trends of immigration policy systems has succeeded in fully integrating immigrants to mainstream society. Culture, language proficiency, the "asymmetry of cultural positions," government in accommodating immigrants in the receiving society are all important means to an end. Nevertheless, willingness of providing material resources, granting rights, and making citizenship trajectories meaningful and valuable to immigrants vary from country to country and oscillate with

\footnotetext{
95 Charles Taylor, Multiculturalism 25 (Princeton University Press, 1994).

96 Linda S. Bosniak, supra note 40.

97 M. P. Vink, supra note 80.
} 
Esta revista forma parte del acervo de la Biblioteca Jurídica Virtual del Instituto de Investigaciones Jurídicas de la UNAM

economic cycles and political positions, making a consistent, coherent and rights based immigration system a target for political and economic governmental agendas.

Since the proclamation of the Universal Declaration of Human Rights, and all the human rights treaties which followed its promulgation, as Benhabib $^{98}$ has asserted, we have entered a phase in the evolution of global civil society that is characterized by a transition from international to cosmopolitan norms of justice which consider individuals as moral and legal persons in a worldwide civil society. The peculiarity of international human rights norms is that that they limit the sovereignty of States, in this case regarding determination of their integration policies for immigrants, as well as oblige them to treat their citizens and residents in accordance with the standards these instruments recognize.

98 S. Benhabib, supra note 91. 